Jurnal Basicedu Volume 5 Nomor 3 Tahun 2021 Halaman 1683-1688

JURNAL BASICEDU

Research \& Learning in Elementary Education

https://jbasic.org/index.php/basicedu

\title{
Persepsi Guru Sekolah Dasar terhadap Pembelajaran Jarak Jauh di Masa Pandemi Covid 19
}

\author{
Fadhilaturrahmi $^{1}$, Rizki Ananda $^{2}$, Sisi Yolanda ${ }^{3}$
}

Pendidikan Guru Sekolah Dasar, Universitas Pahlawan Tuanku Tambusai, Indonesia ${ }^{1,2,3}$

Email : fadhilaturrahmi@universitaspahlawan.ac.id ${ }^{1}$, rizkiananda@universitaspahlawan.ac.id ${ }^{2}$,

Sisiyolandaputri@gmail.com ${ }^{3}$

\begin{abstract}
Abstrak
Penelitian ini bertujuan untuk mengetahui persepsi guru terhadap pembelajaran jarak jauh. Tujuan dari penelitian ini untuk memaparkan informasi terkait persepsi guru mengenai tantangan pelaksanaan pembelajaran jarak jauh di rumah akibat dampak dari pandemi menggunakan WA grup dalam pembelajaran jarak jauh dengan pendekatan deskriptif kualitatif. Penelitian ini di dasari dengan sulitnya mencari data lapangan. Penelitian ini merupakan penelitian deskriptif kualitatif. Informan terdiri dari 9 orang guru yang mana terdiri dari SDN 023 Muara Mahat Baru, SDN 012 langgini dan SDN 018 Langgini. Hasil dari penelitian ini mengunggkapkan bahwa kurang memadainya sarana dan prasarana, kurang maksimalnya penyampaian materi, beban pembelian kuota internet, koneksi internet yang kadang menjadi lamban, gaya belajar yang cendrung visual, peseeta didik malas dalam mengerjakan tugas yang diberikan guru, kurang leluasanya guru dalam mengontrol kegiatan peserta didik, serta materi yang disampaikan guru tidak sepenuhnya di kerjakan oleh peserta didik. Hambatan yang dialami oleh guru dalam pembelajaran jarak jauh adalah sulit mengontrol peserta didik disaat pembelajaran dilakukan tidak dengan tatap muka, sulit memahami perkembangan peserta didik dan peserta didik yang tidak memiliki hp terkadang tidak mengumpulkan tugas yang diberikan guru. Keunggulan dalam pembelajaran jarak jauh yaitu tidak ada sama sekali, karena guru berpendapat bahwa pembelajaran jarak jauh tidak memiliki keunggulan melainkan pembelajaran jarak jauh merugikan orang tua dan peserta didik. Peserta didik lebih sering malas-malasan dalam belajar maupun mengerjakan tugas yang diberikan. Dari 9 hasil wawancara yang didapat oleh peneliti adalah guru kesulitan dalam menyampaikan materi kepada peserta didik karena pembelajaran tidak dilakukan dengan tatap muka sehingga guru tidak tahu sampai mana pemahaman peserta didik. Pembelajaran jarak jauh yang dilakukan tidak efektif karena sulit bagi guru karna sebelumnya belum pernah melakukan pembelajaran jarak jauh.
\end{abstract}

\section{Kata Kunci: Persepsi Guru, Pembelajaran di masa Covid 19}

\begin{abstract}
This study aims to determine the teacher's perception of distance learning. The purpose of this study is to present information related to teacher perceptions regarding the challenges of implementing distance learning at home due to the impact of the pandemic using group WA in distance learning with a qualitative descriptive approach. This research is based on the difficulty of finding field data. This research is a qualitative descriptive study. The informants consisted of 9 teachers which consisted of SDN 023 Muara Mahat Baru, SDN 012 Langgini and SDN 018 Langgini. The results of this study reveal that inadequate facilities and infrastructure, less than optimal delivery of material, the burden of purchasing internet quotas, internet connections that sometimes become sluggish, learning styles that tend to be visual, students are lazy in doing the tasks given by the teacher, the teacher is less flexible in controlling the activities of students, as well as the material presented by the teacher is not fully done by the students. The obstacles experienced by teachers in distance learning are that it is difficult to control students when learning is not done face-to-face, it is difficult to understand the development of students and students who do not have cellphones sometimes do not collect assignments given by the teacher. The advantage in distance learning is that there is none at all, because the teacher believes that distance learning has no advantages but distance learning is detrimental to parents and students. Students are more often lazy in learning and doing the assigned tasks. From the 9 interviews obtained by the researcher, the teacher had difficulty in conveying the material to the students because learning was not done face-to-face so that the teacher did not know the extent of the students' understanding. Distance learning is not effective because it is difficult for teachers because they have never done distance learning before.
\end{abstract}

Keywords: Teacher Percaptions, Learning During The COVID 19

Copyright (c) 2021 Fadhilaturrahmi, Rizki Ananda, Sisi Yolanda

$\bowtie$ Corresponding author:

Address :-

Email : fadhilarurrahmi@universitaspahlawan.ac.id

ISSN 2580-3735 (Media Cetak)

Phone :-

ISSN 2580-1147 (Media Online)

DOI: https://doi.org/10.31004/basicedu.v5i3.1187 
1684 Persepsi Guru Sekolah Dasar terhadap Pembelajaran Jarak Jauh di Massa Pandemi COVID-19-

Fadhilaturrahmi, Rizki Ananda, Sisi Yolanda

DOI: https://doi.org/10.31004/basicedu.v5i3.1187

\section{PENDAHULUAN}

Pandemi Covid 19 adalah krisis kesehatan yang pertama dan terutama di dunia, Banyak negara. Virus Covid 19 sedang melanda dunia saat ini, Covid 19 merupakan keluarga besar virus yang menyebabkan penyakit pada manusia dan hewan. Covid 19 merupakan virus jenis baru yang ditemukan di Wuhan, Hubei, China pada tahun 2019, diberi nama Coronavirus disease-2019 yang disingkat menjadi Covid 19 (Ilmiyah, 2020; Hui, et al., 2020). Covid 19 sejak ditemukan menyebar secara luas hingga mengakibatkan pandemi global yang berlangsung sampai saat ini. Gejala Covid 19 umumnya berupa demam $38^{\circ} \mathrm{C}$, batuk kering, dan sesak nafas serta dampak paling buruk untuk manusia ialah kematian.

Dampak pandemi Covid 19 pada tahun 2020 ini di Indonesia mulai merambah dunia pendidikan, pemerintah pusat hingga daerah memberikan kebijakan untuk meliburkan seluruh lembaga pendidikan. Hal ini dilakukan sebagai upaya mencegah meluasnya penularan virus corona. Diharapkan dengan seluruh lembaga pendidikan tidak melaksanakan aktivitas seperti biasanya, hal ini dapat meminimalisir menyebarnya penyakit covid 19 ini. Hal serupa juga sudah dilakukan oleh berbagai negara yang terpapar penyakit covid 19 ini, kebijakan lockdown atau karantina dilakukan sebagai upaya mengurangi interaksi banyak orang yang dapat memberi akses pada penyebaran virus corona.

Pada tanggal 24 maret 2020 Menteri Pendidikan dan Kebudayaan Republik Indonesia mengeluarkan Surat Edaran Nomor 4 Tahun 2020 Tentang Pelaksanaan Kebijakan Pendidikan Dalam Masa Darurat Penyebaran Covid 19, dalam Surat Edaran tersebut dijelaskan bahwa proses belajar dilaksanakan di rumah melalui pembelajaran daring/jarak jauh dilaksanakan untuk memberikan pengalaman belajar yang bermakna bagi siswa. Belajar di rumah dapat difokuskan pada pendidikan kecakapan hidup antara lain mengenai pandemi Covid 19. Pembelajaran yang dilasanakan pada sekolah dasar juga menggunakan pembelajaran daring/jarak jauh dengan melalui bimbingan orang tua. Siswa dapat berinteraksi dengan guru menggunakan beberapa aplikasi seperti classroom, video converence, telepon atau live chat, zoom maupun melalui whatsapp group. Pembelajaran ini merupakan inovasi pendidikan untuk menjawab tantangan akan ketersediaan sumber belajar yang variatif. Keberhasilan dari suatu model ataupun media pembelajaran tergantung dari karakteristik peserta didiknya. Sebagai mana yang diungkapkan oleh Nakayama (2007: 1) bahwa dari semua literatur dalam e- learning mengindikasikan bahwa tidak semua peserta didik akan sukses dalam pembelajaran online. Ini dikarenakan faktor lingkungan belajar dan karakteristik peserta didik.

Menurut Desiderato dalam Rahmat (2007: 51), persepsi adalah pengalaman tentang objek, peristiwa atau hubungan-hubungan yang diperoleh dengan menyimpulkan informasi dan menafsirkan pesan. Jadi persepsi adalah memberikan makna stimuli inderawi. Menurut Walgito (2010: 99), persepsi merupakan suatu proses yang didahului oleh proses penginderaan, yaitu merupakan proses diterimanya stimulus oleh individu melalui alat indera atau juga disebut proses sensoris.

Berdasarkan observasi wawancara paembelajaran daring yang dilakukan di SDN 023 Muara Mahat Baru, SDN 012 Langgini dan SDN 018 Langgini yang mana menggunakan banyak aplikasi seperti WA, FB dll. Namun belum diketahui seberapa efektif pembelajaran itu dilakukan maka tujuan penelitian ini akan melakukan bagaimana perespsi guru terhadap pembelajaran daring apakah sudah efektif dan apakah ada kendala dalam melakukan pembelajaran daring. Pada akhirnya saya sebagai peneliti memiliki tujuan ingin mengetahui bagaimana persepsi guru terhadap pembelajaran di era covid 19, apakah ada hambatan selama pembelajaran daring, apa keunggulan dan bagaimana upaya mengatasi hambatan tersebut. 
1685 Persepsi Guru Sekolah Dasar terhadap Pembelajaran Jarak Jauh di Massa Pandemi COVID-19-

Fadhilaturrahmi, Rizki Ananda, Sisi Yolanda

DOI: https://doi.org/10.31004/basicedu.v5i3.1187

Tujuan dari penelitian ini adalah untuk mendapatkan informasi mengenai persepsi guru terhadap pembelajaran diera covid 19 di sekolah dasar. Menurut Suranto Aw (2010: 107) Persepsi adalah proses internal yang mana telah diakui oleh individu ketika menyeleksi dan mengatur stimuli yang berasal dari luar. Stimuli ini ditangkap oleh indera yang dimiliki seseorang, kemudian secara spontan perasaan dan pikiran individu akan memberikan makna dari stimuli yang ada tersebut. Secara sederhana, dapat dikatakan jika persepsi adalah proses individu dalam memahami hubungan atau kontak dengan dunia yang ada di sekelilingnya

\section{METODE PENELITIAN}

Metode penelitian ini adalah metode deskriptif kualitatif yang mana penelitian ini didasari dengan sulitnya mencari data lapangan dikarnakan sekolah yang ditutup karena pandemi Covid yang melanda kita semua. Metode deskriptif, yaitu metode yang bersifat memaparkan sejelas-jelasnya tentang objek yang diteliti., serta menggambarkan data secara keseluruhan, sistematis, dan akurat. Adapun rancangan penelitian dimulai dari 1.Pengumpulan Data (data collection) 2. Penyajian Data 3. Reduksi Data 4. Kesimpulan-Kesimpulan Penarikan/Verifikasi. Adapun populasi dan sample yang diambil dalam penelitiannya adalah SDN 023 Muara Mahat Baru, SDN 012 Langgini dan SDN 018 Langgini.

\section{HASIL PENELITIAN DAN PEMBAHASAN}

Berdasarkan deskripsi hasil penelitian ditemukan dari 3 sekolah yang dilakukan peneliti kepada 9 orang guru yang mana semua guru yang diwawancarai menggunakan aplikasi WA grup. Wawancara yang dilakukan di 3 sekolah yang mana melakukan pembelajaran jarak jauh tidak efektif karena sulit untuk dilakukan hal ini disebabkan karena 9 orang guru tersebut belum pernah melakukan pembelajaran jarak jauh sebelumnya dan juga belum pernah melakukan pembelajaran IT. Pembelajaran jarak jauh yang dilakukan tidak efektif karena dengan pembelajaran jarak jauh guru tidak bisa mengetahui sejauh mana kemampuan peserta didik dalam belajar. Setiap tugas yang diberikan guru tidak tahu siapa yang mengerjakan tugas tersebut. Sarana dan prasaranapun juga belum mendukung untuk melakukan pembelajaran jarak jauh.

Aplikasi yang digunakan di dalam pembelajaran jarak jauh ini yaitu hanya aplikasi WA grup tidak ada menggunakan aplikasi media pembelajaran online lainnya. Aplikasi WA grup yang mana ada sebagian guru mengirimkan video pembelajaran saat dia mengajar dan nantinya peserta didik melihat video tersebut dan guru memberikan tugas kepada peserta didik 1x seminggu. Dengan pembelajaran jarak jauh dengan tidak tatap muka dengan peserta didik langsung membuat kesulitan guru dalam menilai, guru hanya bisa mengambil nilai dari tugas yang diberikan dan dikumpulkan peserta didik setiap minggunya. Dan ada juga beberapa anak tidak memiliki hp dan disitulah guru mengambil tindakan untuk mendatangi rumah peserta didik tersebut. Pemnelajaran jarak jauh dilakukan oleh beberapa guru juga dengan belajar bersama dirumah guru tersebut seperti membagi kelompok belajar setiap harinya. Pembegian kelompok yang dilakukan dengan 2 kelompok 1 hari yang terdiri dari 5 sampai 6 orang. Bagi peserta didik yang tidak paham dengan materi pembelajaran disuruh untuk belajar lagi dirumah dengan orang tua.

Pembelajaran jarak jauh yang dilakukan di kelas rendah membuat kesulitan bagi guru dalam menghadapi peserta didik yang tidak bisa membaca dan menulis, dikarenakan mereka tidak bisa tatap muka lagi dengan itu guru bekerja sama dengan orang tua agar lebih memperhatikan peserta didik dirumah, agar lebih giat untuk membaca dan menulis. Ada juga sebagian guru melakukan dengan cara menyuruh peserta didik 
1686 Persepsi Guru Sekolah Dasar terhadap Pembelajaran Jarak Jauh di Massa Pandemi COVID-19-

Fadhilaturrahmi, Rizki Ananda, Sisi Yolanda

DOI: https://doi.org/10.31004/basicedu.v5i3.1187

kerumahnya untuk membaca dan menulis. Pembelajaran jarak jauh tidak jauh dari pantauan orangtua yang mana guru meminta kerjasama dengan orang tua, ada sebagian orang tua yang mengeluh saat peserta didik tidak ingin mengerjakan tugas yang diberikan, guru pun juga merasa tugas yang dikumpulkan itu tidak mutlak di kerjakan oleh peserta didik.

Berdasarkan penelitian yang dilakukan dapat disimpulkan bahwasanya persepsi guru terhadap pembelajaran jarak jauh ini belum efektif untuk dilakuakan karena rata-rata guru menjawab banyak kendala seperti media pembelajaran terbatas, pengetahuan peserta didik tidak diketahui.pembelajaran jarak jauh yang dilakukan tidak hanya guru yang terlibat tetapi orang tua juga ikut serta dalam pembelajaran, seperti mengontrol peserta didik saat tugas yang diberikan guru dan memberi masukan terhadap peserta didik yang tidak mau untuk mengerjakan tugasnya. Jadi pembelajaran jarak jauh tidaklah memuaskan untuk dilakukan karena pembelajaran jarak jauh tidak tatap muka dengan peserta didik, dan tidak mengetahui sejauh mana peserta didik memahami pembelajaran dan tidak tahu perkembangan peserta didik. Pembelajaran jarak jauh tidak efektif dilakukan untuk peserta didik karena peserta didik lebih banyak bermain dan tugas yang diberikan guru orang tua yang mengerjakannya. Dampak dari pandemic Covid 19 mengunggkapkan bahwa kurang memadainya sarana dan prasarana, kurang maksimalnya penyampaian materi, beban pembelian kuota internet, koneksi internet yang kadang menjadi lamban, gaya belajar yang cendrung visual, peseeta didik malas dalam mengerjakan tugas yang diberikan guru, kurang leluasanya guru dalam mengontrol kegiatan peserta didik, serta materi yang disampaikan guru tidak sepenuhnya di kerjakan oleh siswa. Dari 9 hasil wawancara yang didapat oleh peneliti adalah guru kesulitan dalam menyampaikan materi kepada peserta didik karena pembelajaran tidak dilakukan dengan tatap muka sehingga guru tidak tahu sampai mana pemahaman peserta didik. Pembelajaran jarak jauh yang dilakukan tidak efektif karena sulit bagi guru karna sebelumnya belum pernah melakukan pembelajaran jarak jauh.

\section{SIMPULAN}

Penelitian deskriptif kualitatif yang digunakan untuk mendeskripsikan persepsi guru terhadap pembelajaran di era Covid 19 di sekolah dasar. Penelitian ini dilakukan karna sulitnya mencari data lapangan di akibatkan adanya pandemi Covid 19. Dari hasil wawancara yang dilakukan terhadap III sekolah yaitu SDN 023 Muara mahat baru, SDN 012 langgini dan SDN 018 Langgini dapat disimpulkan bahwa penelitian ini mengungkapkan masih kurang memadainya sarana dan prasarana, kurang maksimalnya penyampaian materi, beban pembelian kuota internet, konseksi internet yang kadang menjadi lamban, gaya belajar yang cendrung visual, peserta didik malas dalam mengerjakan tugas yang diberikan guru, serta materi yang disampaikan guru tidak sepenuhnya dikerjakan sepenuhnya oleh peserta didik, ini peserta didik tidak dapat memahami pelajaran dengan baik dan dengan adanya pandemi Covid 19 ini peserta didik dan guru tidak bisa melakukan pembelajaran dengan tatap muka. Hambatan yang dialami oleh guru dalam pembelajaran jarak jauh adalah sulit mengontrol peserta didik disaat pembelajaran dilakukan tidak dengan tatap muka, sulit memahami perkembangan peserta didik dan peserta didik yang tidak memiliki hp terkadang tidak mengumpulkan tugas yang diberikan guru. Keunggulan dalam pembelajaran jarak jauh yaitu tidak ada sama sekali, karena guru berpendapat bahwa pembelajaran jarak jauh tidak memiliki keunggulan melainkan pembelajaran jarak jauh merugikan orang tua dan peserta didik. peserta didik lebih sering malas-malasan dalam belajar maupun mengerjakan tugas yang diberikan. Pembelajaran jarak jauh yang dilakukan kurang 
1687 Persepsi Guru Sekolah Dasar terhadap Pembelajaran Jarak Jauh di Massa Pandemi COVID-19-

Fadhilaturrahmi, Rizki Ananda, Sisi Yolanda

DOI: https://doi.org/10.31004/basicedu.v5i3.1187

efektif karena sulit untuk dilakukan hal ini disebabkan karena 9 orang guru yang diwawancarai belum pernah melakukan pembelajaran jarak jauh.

\section{DAFTAR PUSTAKA}

Arnesti, N., \& Hamid, A. (2015). Penggunaan Media Pembelajaran Online - Offline Dan Komunikasi Interpersonal Terhadap Hasil Belajar Bahasa Inggris. Jurnal Teknologi Informasi \& Komunikasi Dalam Pendidikan, 2(1).

Aw, Suranto. 2010. Komunikasi Sosial Budaya. Yogyakarta : GRAHA ILMU

Beam, p.(1997). Brenking the sprinter writ: Achieving Cost-Efectiveness in Online Learning. Paper prensented at thr International Symponsium on Distabce Education and Open Learning, orginized by MODE Indonesia. IDLN, SEAMOLEC, ICDE< UNDP and UNESCO Tuban, Bali, Indonesia.

Bentley, Y., Selassie, H., \& Shegunshi, A. (2012). Design and Evalutation of Student-Focused eLearning Elektronik Journal of E-Learning, 10(1),1-2.

Bimo, Walgito. (2010). Pengantar Psikologi Umum. Yogyakarta: C.V Andi.

Bullen, M. (2001). E-Lerning and thr iInternationalization Education, Malaysian Journal of Education Tecahology 1 (1), 37-46

Daryanto. 2010. Belajar dan Mengajar. Bandung: Yrama Widya.

Depdiknas. 2005. Peraturan Pemerintah Republik Indonesia No. 19 Tahun 2005 Tentang Standar Nasional Pendidikan. Jakarta: Dep Dik Nas

Echols, J.M. Dan Shadily, H. 2002. Kamus Inggris Indonesia. Jakarta: PT Gramedia.

Fadila, Dewi \& Ridho, Sari Lestari Zainal. 2013. Perilaku Konsumen. Palembang: Penerbit Citrabooks Indonesia.

Fadila, Dewi \& Ridho, Sari Lestari Zainal. 2013. Perilaku Konsumen. Palembang: Penerbit Citrabooks Indonesia.

Hidayat, (2013). Metode Penelitian Keperawatan dan Tehnik Analisa Data. Jakarta : Salemba Medika.

Rahmat Kriyantono, 2007, Teknik Praktis Riset Komunikasi, Jakarta Prenada Media Group.

Robbins, Stephen P, 2007. Perilaku Organisasi Buku 1, (Jakarta: Salemba Empat), hal. 174184(wikipedia.com).

Sanjaya, R. (Ed.). (2020). 21 Refleksi Pembelajaran Daring di Masa Darurat. SCU Knowledge Media.

Sevima. (2020). 5 Kebijakan Pendidikan Masa Darurat Corona. KINDERGARTEN: Journal Of Islamic Early Childhood Education | 58

Sukardi. 2010. Metodologi Penelitian Pendidikan. Jakarta : PT. Bumi Aksara.

Trianto. 2010. Pengantar Penelitian Pendidikan Bagi Pengembangan Profesi Pendidikan \& Tenaga Kependidikan. Jakarta: Kencana.

Walgito Bimo,1990, Psikologi Sosial, Yogyakarta, Andi

Walgito, Bimo. 2010. Pengantar Psikologi Umum. Yogyakarta: CV. ANDI OFFSET.

Wardani. 2007. Peran Guru SD Dalam Pendidikan. Www.Gurukelas.Com.Diakses 8-10-2014 
1688 Persepsi Guru Sekolah Dasar terhadap Pembelajaran Jarak Jauh di Massa Pandemi COVID-19Fadhilaturrahmi, Rizki Ananda, Sisi Yolanda DOI: https://doi.org/10.31004/basicedu.v5i3.1187

Wibowo. 2013. Manajemen Kinerja. Jakarta: Rajawali Pers

Yanti, M. T., Kuntarto, E., \& Kurniawan, A. R. (2020). Pemanfaatan Portal Rumah Belajar Kemendikbud Sebagai Model Pembelajaran Daring di Sekolah Dasar. Adi Widya: Jurnal Pendidikan Dasar, 5(1), 61 68 . 